\title{
Tingkat Konversi dan Efisiensi Pakan Benih Ikan Bawal Bintang (Trachinotus blochii) dengan Frekuensi Pemberian Berbeda
}

\section{Conversion Rate and Feed Efficiency of Silver Pompano Fish (Trachinotus blochii) With Different Frequency Giving}

\author{
Ibrahim Saputra ${ }^{1}$, Wiwin Kusuma Atmaja Putra ${ }^{2 *}$, Tri Yulianto ${ }^{3}$ \\ Program Studi Budidayaa Perairan, Fakultas Ilmu Kelautan dan Perikanan \\ *Email: wiwinbdp@umrah.ac.id
}

\begin{abstract}
Abstrak
Nilai tingkat konversi dan efisiensi pakan merupakan parameter penentuan kualitas, perlakuan, atau pakan yang diberikan terhadap pertumbuhan ikan Bawal Bintang (Trachinotus blochii). Tujuan penelitian ini adalah mengetahui pengaruh frekuensi pemberian pakan terhadap konversi dan efisiensi pakan dan kelangsungan hidup ikan Bawal Bintang. Metode penelitian yang digunakan adalah Rancangan Acak Lengkap (RAL) dengan 3 perlakuan (Kontrol yaitu pemberian pakan 1 hari sekali, A yaitu pemberian pakan 2 hari sekali,dan B yaitu pemberian pakan 3 hari sekali) dengan 3 ulangan. Hasil penelitian terbaik adalah perlakuan Kontrol sebesar $2.11 \mathrm{~g}$ (nilai konversi pakan), $47.32 \%$ (efisiensi pakan), dan 100\% (kelangsungan hidup). Kesimpulan penelitian ini adalah perlakuan yang diberikan selama penelitian secara analisis ANOVA tidak memberi pengaruh yang nyata terhadap nilai konversi dan efisiensi pakan. Pemberian pakan dengan frekuensi 1 kali sehari (kontrol) menunjukkan pertumbuhan bobot terbaik dan dapat diterapkan pada budidaya.
\end{abstract}

Kata kunci : Tingkat konversi, Efisiensi pakan, Ikan Bawal Bintang,

\begin{abstract}
The value of conversion rate and feed efficiency is a parameter for determining the quality, treatment, or feed given to the growth of Silver Pompano (Trachinotus blochii). The purpose of this study was to determine the effect of feeding frequency on feed conversion and efficiency and survival of Silver Pompano. The research method used was a Completely Randomized Design (RAL) with 3 treatments (Control namely feeding once a day, A was feeding 2 days, and B was feeding once every 3 days) with 3 replications. The best results were $\mathrm{K}$ treatment at $2.11 \mathrm{~g}$ (feed conversion ratio), $47.32 \%$ (feed efficiency), and 100\% (survival). The conclusion of this study is that the treatment given during the study by ANOVA analysis did not give a significant effect on the conversion value and feed efficiency. Feeding with a frequency of 1 time a day (control) shows the best weight growth and can be applied to cultivation.
\end{abstract}

Keywords: conversion rate, feed efficiency, Silver Pompano 
Journal of Aquaculture Science

DOI: https://doi.org/10.31093/joas.v3i2.56

PENDAHULUAN

Ikan bawal bintang (T. blochii, Lacepede) merupakan ikan yang tergolong baru dibudidayakan di Indonesia pada tahun 2007. Pembenihan ikan Bawal Bintang telah berhasil dilakukan di Balai Budidaya Laut Batam untuk pertama kalinya di Indonesia (Minjoyo dkk., 2008). Ikan Bawal Bintang merupakan menjadi salah satu komoditi utama selain kerapu dan kakap yang dibudidayakan di Kepulauan Riau.

Permasalahan yang masih ditemukan pada proses pendederan hingga pembesaran Ikan bawal bintang di antaranya sisa pakan. Sisa pakan menyebabkan pencemaran pada lingkungan perairan yang disebabkan oleh kegiatan budidaya bersumber dari buangan pakan yang tidak terkonsumsi (Dias, 2012), bahan sisa metabolik atau feses dan urin (Erlania dkk, 2010). Upaya yang dapat dilakukan untuk mengurangi dampak pencemaran yang terjadi karena sisa pakan yaitu dengan memberikan takaran dan frekuensi yang tepat dalam pemberian pakan sehingga dapat dimanfaatkan untuk pertumbuhan ikan.
April 2018 vol 3 (2): 72-84

Online pada http://joas.co.id

Pemberian pakan yang berlebihan dapat mengakibatkan pencemaran dan pakan tidak terkonsumsi sehingga pengelolaan pakan tidak efektif dan efisien.

Meningkatkan nilai konversi dan efisiensi pakan ikan dapat dengan alokasi waktu yang disebut sebagai frekuensi pemberian pakan (Galano et al., 2003). Frekuensi pemberian pakan adalah jumlah pengulangan pemberian pakan dalam satu hari. Jadwal pemberian pakan sebaiknya disesuaikan dengan nafsu makan ikan dengan frekuensi $4-5$ kali sehari, waktu pemberian pakan bisa pagi, siang, sore, dan malam hari (Dardiani dan Sary, 2010).

Frekuensi pemberian pakan pada benih ikan harus lebih sering karena laju evakuasi pakan di dalam lambung atau pengosongan lambung ini tergantung pada ukuran dan jenis ikan kultur serta suhu air (Effendi, 2002). Penelitian mengenai frekuensi pemberian pakan telah dilakukan pada beberapa spesies ikan, di antaranya Groat (2002) dan Kayano et al., (1993).

Tujuan dari penelitian ini adalah mengetahui tingkat konversi dan efisiensi pakan ikan Bawal 
Journal of Aquaculture Science

DOI: https://doi.org/10.31093/joas.v3i2.56
April 2018 vol 3 (2): 72-84

Online pada http://joas.co.id
Bintang yang diberi perlakuan frekuensi pemberian pakan yang berbeda dan mengetahui frekuensi pemberian pakan terbaik dalam penelitian ini untuk meningkatkan nilai konversi dan efisiensi pakan ikan Bawal Bintang.

\section{METODE PENELITIAN}

\section{Waktu dan Tempat}

Penelitian ini dilaksanakan pada tanggal 06 Juni - 03 Juli 2017 di Balai Benih Ikan (BBI) Pengujan, Kabupaten Bintan, Kepulauan Riau.

\section{Bahan dan Alat}

Bahan yang digunakan dalam penelitian ini adalah benih ikan bawal bintang (Trachinotus blochii) dengan bobot $3 \pm 0,5 \mathrm{~g}$, pellet merk Megami PN-1. Peralatan yang digunakan pada penelitian ini adalah $\begin{array}{llllll}\text { akuarium ukuran } & 80 & \text { x } & 40 & \text { x } & 40\end{array}$ sebanyak 9 buah, serokan, penggaris, timbangan analitik $0.5 \mathrm{~g}$, thermometer, DO meter dan refraktometer.

\section{Prosedur Kerja}

Penelitian ini dilakukan secara eksperimental dengan menggunakan metode Rancangan Acak Lengkap (RAL) dengan 3 perlakuan dan 3 ulangan. Setiap ulangan ditebar benih Ikan bawal bintang sebanyak 15 ekor. Perlakuan yang diberikan adalah frekuensi waktu pemberian pakan pada Ikan bawal bintang antara lain : perlakuan K (Kontrol) dengan frekuensi pemberian pakan adalah 1 hari sekali; perlakuan A (Perlakuan 1) dengan frekuensi pemberian pakan 2 hari sekali; dan perlakuan B (Perlakuan 2) dengan frekuensi pemberian pakan 3 hari sekali

\section{Persiapan Wadah}

Masa pemeliharaan ikan diawali dengan penyiapan wadah. Penyiapan wadah meliputi pembersihan akuarium, pengaturan letak wadah, penyiapan aerasi, selang output, dan penyiapan air.

\section{Pemberian Pakan}

Jenis pakan yang diberikan adalah berupa pellet kering yang ukurannya disesuaikan dengan bukaan mulut ikan. Ikan diaklimatisasikan pakan terlebih dahulu selama satu minggu. Kandungan nutrisi pada pellet merk Megami yaitu protein $37 \%$, lemak $3 \%$, kadar abu $11 \%$, serat kasar $2 \%$. 


\section{Persiapan dan Penebaran Benih}

Persiapan ikan meliputi penimbangan bobot dan pengukuran panjang tubuh ikan, agar didapatkan ikan yang seragam. Ikan bawal bintang dengan bobot $3 \pm 0,5 \mathrm{~g} /$ ekor dan panjang $6 \pm 0,5 \mathrm{~cm} /$ ekor. Ikan dipuasakan satu hari dengan tujuan agar lambung ikan kosong pada saat penimbangan untuk mengetahui berat bersih ikan. Kemudian ikan dimasukkan ke dalam wadah penelitian dengan padat penebaran yang digunakan 15 ekor dalam satu wadah.

\section{Pemeliharaan Benih}

Pemeliharaan benih meliputi penyiponan, pergantian air, pengecekan kualitas air, pengecekan kesehatan dan kematian ikan. Pemberian pakan menggunakan feeding rate $6 \%$ dari biomassa. Penyiponan dilakukan sebelum pergantian air dan dilakukan satu kali sehari pada saat sebelum pemberian pakan ikan pada pagi hari.

\section{Parameter Penelitian}

FCR (Feed Covertion Ratio)

Rasio konversi pakan dihitung menurut Effendie (1997), sebagai berikut :

$$
\mathrm{FCR}=\frac{\mathrm{F}}{(\mathrm{Wt}+\mathrm{D})-\mathrm{Wo}}
$$

Keterangan :

$$
\begin{array}{llll}
\text { FCR } & : \text { Rasio Konversi Pakan } \\
\mathrm{F} & : \text { Jumlah total pakan yang } \\
& \text { diberikan }(\mathrm{g}) \\
\mathrm{Wt} & : \begin{array}{l}
\text { Bobot total ikan pada akhir } \\
\text { penelitian }(\mathrm{g})
\end{array} \\
\mathrm{Wo}: \begin{array}{l}
\text { Bobot total ikan pada awal } \\
\text { penelitian }(\mathrm{g})
\end{array} \\
\mathrm{D} & : \begin{array}{l}
\text { Bobot ikan yang mati selama } \\
\text { penelitian }(\mathrm{g})
\end{array}
\end{array}
$$

\section{Efisiensi Pakan}

Efisiensi Pakan (EP) dihitung berdasarkan rumus Effendie (1997) sebagai berikut :

$$
\mathrm{EP}=\frac{(\mathrm{Wt}+\mathrm{D})-\mathrm{Wo}_{0}}{\mathrm{~F}} \times 100 \%
$$

Keterangan :

EP : Efesiensi Pakan (\%)

$\mathrm{W}_{\mathrm{t}}$ : Bobot rata - rata ikan pada akhir penelitian $(\mathrm{g})$

$\mathrm{W}_{0} \quad$ : Bobot rata - rata ikan pada awal penelitian (g)

F : Jumlah total pakan ikan yang diberikan $(\mathrm{g})$

D : Bobot ikan yang mati selama penelitian $(\mathrm{g})$

\section{Pertumbuhan Panjang Mutlak}

Pertumbuhan panjang mutlak (L) dihitung dengan rumus Effendie (1997), sebagai berikut :

$$
\mathrm{L}=\mathrm{L}_{\mathrm{t}}-\mathrm{L}_{0}
$$

Keterangan :

L : Pertumbuhan panjang $(\mathrm{cm})$

$\mathrm{L}_{\mathrm{t}} \quad$ : Panjang ikan pada waktu $\mathrm{t}(\mathrm{cm})$

$\mathrm{L}_{0} \quad$ : Panjang ikan pada waktu awal penelitian $(\mathrm{cm})$ 
Journal of Aquaculture Science

DOI: https://doi.org/10.31093/joas.v3i2.56
April 2018 vol 3 (2): 72-84

Online pada http://joas.co.id

\section{Pertumbuhan Bobot Mutlak}

Pertumbuhan rata-rata setiap

hari dihitung menggunakan rumus

Effendie (2002),

$$
\mathrm{W}=\mathrm{W}_{\mathrm{t}}-\mathrm{W}_{0}
$$

Keterangan :

W : Pertumbuhan Mutlak(g)

$\mathrm{W}_{\mathrm{t}}$ : Bobot ikan pada waktu $\mathrm{t}(\mathrm{g})$

$\mathrm{W}_{0}$ : Bobot ikan pada waktu awal penelitian $(\mathrm{g})$

\section{Analisis Data}

Data yang diperoleh kemudian dihitung diamati dan dianalisis berdasarkan parameter. Hasil perhitungan setiap parameter dianalisis secara deskriptif serta ditampilkam dalam bentuk grafik, tabel, dan gambar.

\section{HASIL}

\section{Konversi Pakan}

Hasil yang diperoleh dari penelitian tentang penghitungan parameter konversi pakan ikan Bawal Bintang selama pemeliharaan 28 hari dapat dilihat pada Gambar 1.

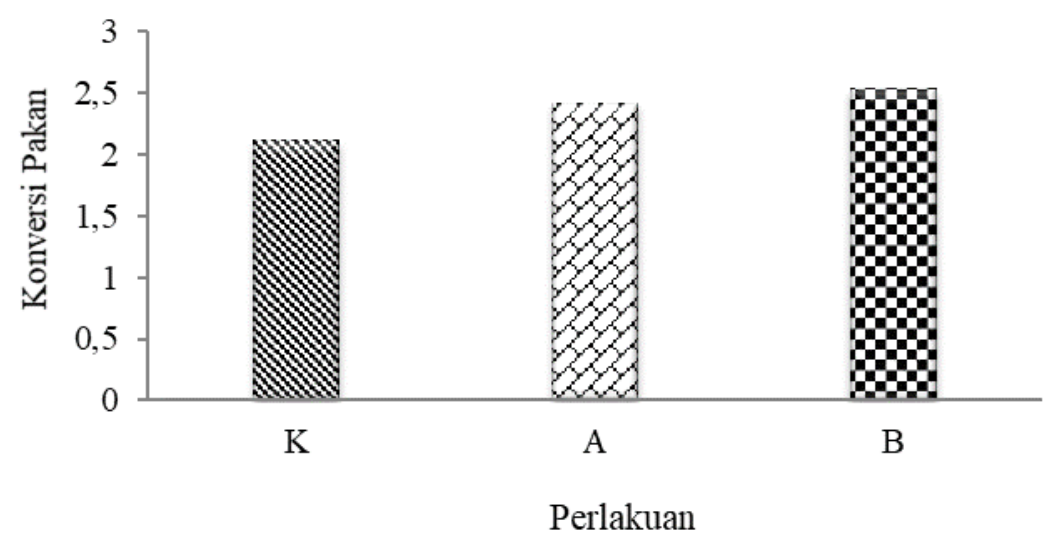

Gambar 1. Nilai konversi pakan ikan Bawal Bintang setiap perlakuan selama penelitian. Keterangan : K (Kontrol) Frekuensi pemberian 1 hari sekali; A (Perlakuan Frekuensi pemberian pakan 2 hari sekali); B (Perlakuan Frekuensi pemberian pakan 3 hari sekali).

Hasil penelitian berdasarkan

Gambar 1 diketahui bahwa nilai konversi pakan terendah dalam penelitian ini adalah perlakuan kontrol dengan dengan nilai konversi pakan sebesar 2,11. Sedangkan nilai konversi pakan tertinggi terdapat pada perlakuan $\mathrm{B}$ dengan nilai konversi pakan sebesar 2,53. 


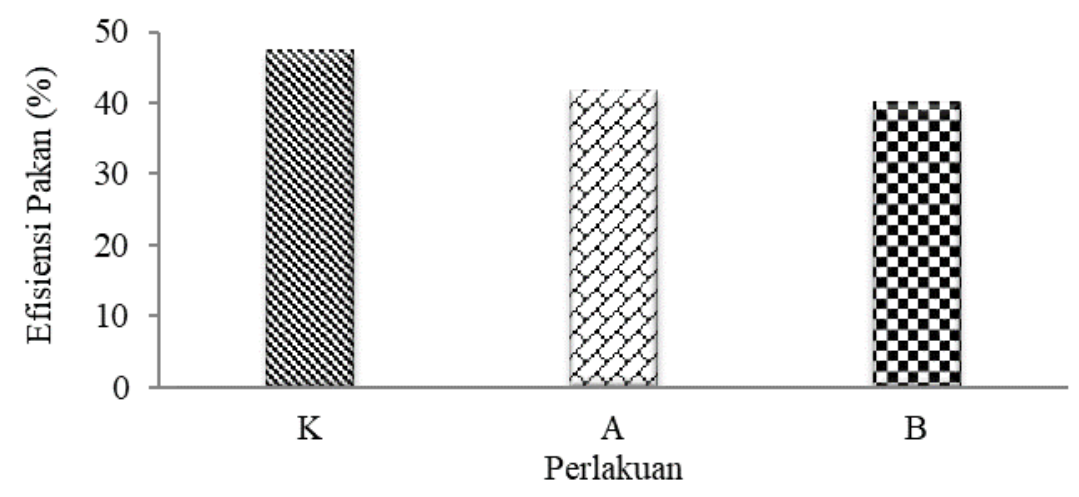

Gambar 2. Persentase efisiensi pakan ikan Bawal Bintang setiap perlakuan : K (Kontrol) Frekuensi pemberian 1 hari sekali; A (Perlakuan Frekuensi pemberian pakan 2 hari sekali); B (Perlakuan Frekuensi pemberian pakan 3 hari sekali).

\section{Efisiensi Pakan}

Efisiensi pakan ikan Bawal Bintang selama penelitian dapat dilihat pada Gambar 2. Hasil penelitian berdasarkan Gambar 2 persentase efisiensi pakan setiap perlakuan yaitu K (47,32\%), A $(41,66 \%)$, dan B $(39,93 \%)$. Hasil terbaik adalah perlakuan kontrol .

\section{Pertumbuhan Bobot Mutlak}

Hasil dari pengamatan penelitian yang dilaksanakan selama 28 hari diperoleh pertumbuhan ratarata individu ikan Bawal Bintang yang berbeda-beda pada tiap perlakuan. Hasil penelitian tentang parameter pertumbuhan bobot mutlak dilihat pada Gambar 3.

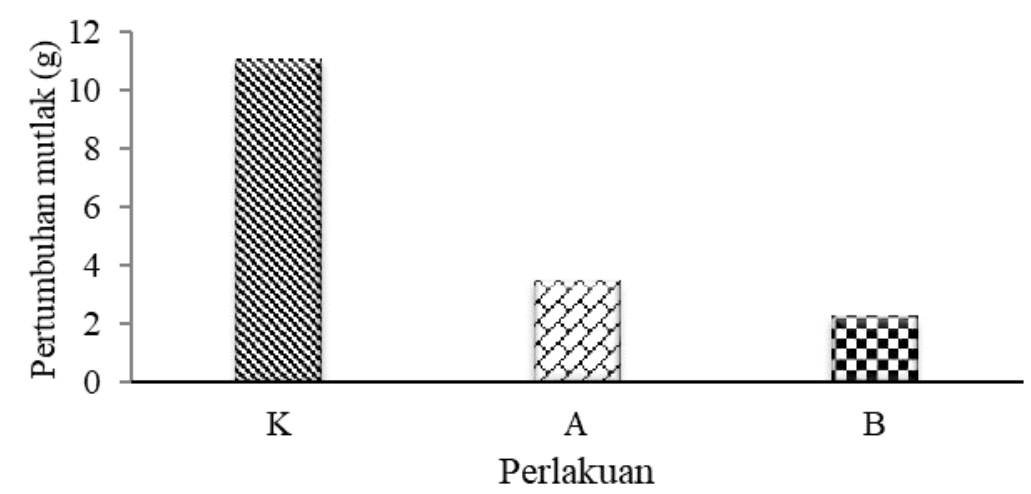

Gambar 3. Pertumbuhan bobot mutlak ikan Bawal Bintang setiap perlakuan : K (Kontrol) Frekuensi pemberian 1 hari sekali; A (Perlakuan Frekuensi pemberian pakan 2 hari sekali); B (Perlakuan Frekuensi pemberian pakan 3 hari sekali). 
Hasil penelitian berdasarkan

Gambar 3 pertumbuhan bobot mutlak setiap perlakuan yaitu $\mathrm{K}$ $(11,12 \mathrm{~g}), \mathrm{A}(3,49 \mathrm{~g})$ dan B $(2,25 \mathrm{~g})$. Perlakuan terbaik adalah perlakuan kontrol
Hasil penelitian parameter pertumbuhan panjang mutlak ikan Bawal Bintang selama pemeliharaan 28 hari dapat dilihat pada Gambar 4 dibawah ini

\section{Pertumbuhan Panjang Mutlak}

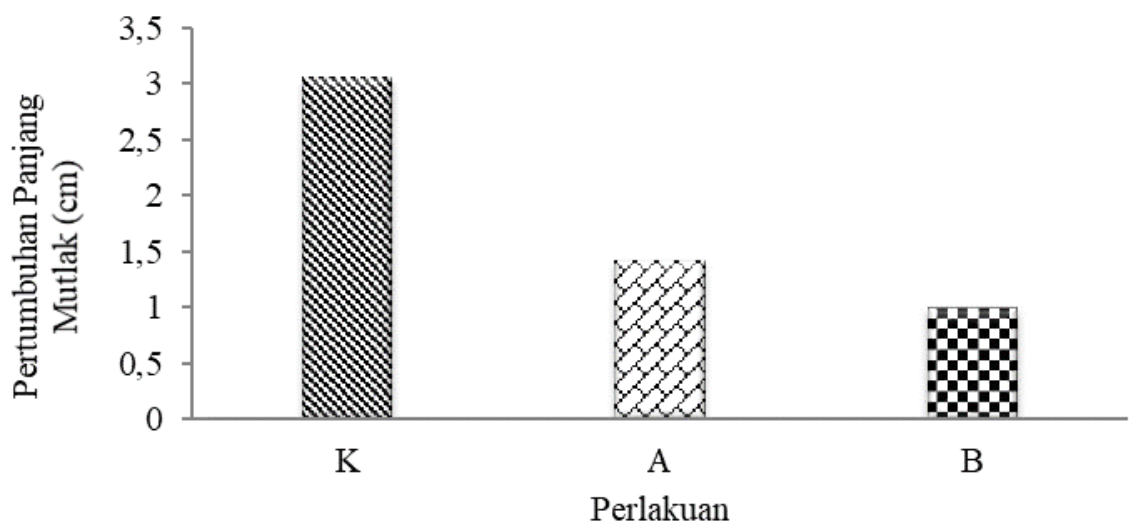

Gambar 4. Pertumbuhan panjang mutlak ikan Bawal Bintang setiap perlakuan : K (Kontrol) Frekuensi pemberian 1 hari sekali; A (Perlakuan Frekuensi pemberian pakan 2 hari sekali); B (Perlakuan Frekuensi pemberian pakan 3 hari sekali).

Hasil penelitian berdasarkan

Gambar 4, diketahui bahwa pertumbuhan panjang mutlak setiap perlakuan yaitu $\mathrm{K}(3,05 \mathrm{~cm}), \mathrm{A}$ $(1,42 \mathrm{~cm})$ dan B $(1,00 \mathrm{~cm})$. Hasil yang terbaik terdapat pada perlakuan kontrol.

\section{PEMBAHASAN}

Nilai Konversi pakan yang terbaik terdapat pada perlakuan $\mathrm{K}$ yaitu sebesar $2,11 \mathrm{~g}$. Hasil penelitian pada perlakuan A dan B lebih tinggi dibanding perlakuan $\mathrm{K}$ dikarenakan adanya peningkatan konsumsi pada saat ikan dipuasakan. Hal ini sesuai dengan pernyataan Darmoni dan Kadari (2007), bahwa hiperfagia merupakan kondisi nafsu makan meningkat setelah ikan mengalami pemuasaan, sehingga meningkatkan konsumsi pakan ketika pemberian pakan kembali.

Nilai konversi pakan dapat diartikan bahwa untuk meningkatkan atau menghasilkan $1 \mathrm{~kg}$ bobot tubuh ikan Bawal Bintang dibutuhkan 2,11 
Journal of Aquaculture Science

DOI: https://doi.org/10.31093/joas.v3i2.56
April 2018 vol 3 (2): 72-84

Online pada http://joas.co.id $\mathrm{kg}$ pakan. Hal ini sesuai dengan pendapat dari Sih Yang Sim et al. (2005), yang menyatakan bahwa nilai rasio konversi pakan pellet untuk ikan laut adalah 1,67, sementara untuk FCR pakan rucah adalah 6,0. Penelitian lain pada ikan Kerapu Bebek dengan pemberian pakan buatan menghasilkan nilai rasio konversi pakan 1,54 (Suwirya dkk., 2005).

Perlakuan $\mathrm{K}$ memiliki tingkat effisiensi pakan lebih baik karena memiliki nilai konversi pakan yang lebih rendah. Seperti pernyataan Fran dkk (2011), bahwa nilai konversi pakan digunakan untuk mengetahui baik buruknya kualitas pakan yang diberikan untuk pertumbuhan ikan. Rendahnya konversi pakan berarti makin tinggi efisiensi pakan tersebut dan sebaliknya makin tinggi nilai konversi pakan maka makin rendah efisiensinya.

Nilai rasio konversi pakan ikan Bawal Bintang secara keseluruhan berkisar antara 2,11-2,53 g. Jika dibandingkan dengan hasil penelitian Darmoni dan Kadari (2007), bahwa rasio konversi pakan ikan Bawal Bintang umumnya berkisar antara 1,25-2,43 g dengan nilai FCR terbaik pada pakan sebesar $1 \%$ dari bobot tubuh. Selanjutnya penelitian yang dilakukan oleh Jayakumar et al. (2014), nilai FCR untuk ikan bawal bintang berkisar antara 2,13-3,0 g. Artinya data hasil penelitian yang diperoleh mendekati nilai FCR pada penelitian tersebut, meskipun nilai FCR yang diperoleh dari penelitian ini lebih tinggi.

Berdasarkan hasil pengamatan efisiensi pakan ikan Bawal Bintang dengan perlakuan kontrol yakni pemberian pakan dengan interval 1 hari 1 kali memiliki nilai yang paling tinggi dibanding dengan perlakuan A (pemberian pakan 2 hari sekali) dan perlakuan B (pemberian pakan 2 hari sekali). Hal ini menunjukkan bahwa semakin sering ikan Bawal Bintang diberi pakan dengan interval pendek maka akan semakin tinggi pula nilai efisiensi pakannya.

Pemberian pakan dengan interval waktu yang lebih cepat akan memberikan asupan protein lebih banyak dibandingkan dengan ikan yang diberikan pakan dengan interval lebih lama. Hal ini sesuai dengan penyataan Zulkhasyni dkk (2016), bahwa kecernaan protein cenderung meningkat dengan 
semakin meningkatnya kadar protein dalam pakan. Peningkatan kadar protein pada pakan tentunya dipengaruhi oleh frekuensi pemberian pakan yang lebih cepat dibandingkan dengan pemberian pakan dengan frekuensi yang lebih lama.

Effisiensi pakan yang lebih tinggi pada perlakuan $\mathrm{K}$ dipengaruhi oleh tingginya kadar protein dibandingkan dengan perlakuan A dan B. Frekuensi waktu pemberian pakan yang lebih cepat akan memberikan asupan protein lebih tinggi sehingga berpengaruh terhadap effisiensi pakan ikan Bawal Bintang. Fran dkk. (2011), menyatakan tingkat energi protein yang terdapat di dalam pakan ikan berpengaruh pada tingkat efisiensi dan efektifitas dalam pemanfaatan pakan.

Konversi dan efisiensi pakan erat kaitannya dengan nilai kecernaan. Semakin besar nilai kecernaan suatu pakan maka semakin banyak nutrisi dalam pakan yang dimanfaatkan untuk pertumbuhan ikan, (Hanief dkk., 2014). Mengacu pada pendapat tersebut, diasumsikan bahwa semakin sering pemberian pakan pada perlakuan $\mathrm{K}$ (1 hari 1 kali) memberikan persentase nutrisi yang lebih tinggi dibandingkan dengan perlakuan A (2 hari 1 kali) dan perlakuan B (3 hari 1 kali).

Pertumbuhan ikan Bawal Bintang tertinggi pada perlakuan K. Hal ini dapat disebabkan karena pengaruh dari pemberian nutrisi yang lebih banyak. Taufiq dkk (2016), menyatakan bahwa pakan merupakan sumber energi bagi ikan untuk bergerak, tumbuh dan bertahan terhadap penyakit. Nilai pertumbuhan bobot dan panjang mutlak terbaik terdapat pada perlakuan K (kontrol). Retnani dan Abdulgani (2012), menyatakan bahwa faktor yang berpengaruh dalam pertumbuhan ikan antara lain adalah kondisi lingkungan, ukuran, umur, densitas stok serta pakan yang diberikan. Juniyanto dkk. (2014), menyatakan bahwa interval pemberian pakan yang tepat dengan ukuran bobot ikan Bawal Bintang $3 \mathrm{~g}$ adalah 4 kali sehari.

Pemberian pakan dengan interval waktu 3 kali sehari akan lebih tinggi pertumbuhannya dibandingkan pemberian pakan dengan interval waktu 1 hari sekali 
(Hanief dkk., 2014). Diduga waktu pemberian pakan pada perlakuan dengan interval yang lebih pendek sesuai dengan laju pengosongan isi lambung. Pada saat lambung ikan mulai kosong maka ikan akan segera merespon pakan yang diberikan.

Penambahan bobot ikan Bawal Bintang dipengaruhi oleh nutrisi yang diserap oleh ikan dan dimanfaatkan menjadi sumber energi untuk tumbuh dan berkembang. Sumber asam lemak. Pertumbuhan berat ikan terjadi akibat metabolisme tubuh ikan yang bekerja secara baik setelah ikan mengkonsumsi pakan (Nuhman. 2008). Pertumbuhan harian berfungsi untuk menghitung persentase pertumbuhan berat ikan perhari. Pertumbuhan sebagai pertambahan berat dalam waktu tertentu (Yenni dkk., 2010).

Pemberian pakan dengan frekuensi yang lebih sering akan menunjukkan pertumbuhan yang lebih baik. Hal ini diduga karena jumlah pakan yang diberikan mendekati kapasitas tampung lambung ikan sehingga pakan yang diberikan dapat dikonsumsi dan dicerna dengan sempurna oleh ikan. Handajani dan Widodo (2010), menyatakan bahwa pertumbuhan ikan dipengaruhi oleh faktor dari dalam dan faktor dari luar. Faktor dari dalam meliputi sifat keturunan, ketahanan terhadap penyakit dan kemampuan dalam memanfaatkan makanan. Sedangkan faktor dari luar meliputi sifat fisika, kimia dan biologi perairan.

Berdasarkan dari hasil penelitian diketahui bahwa laju pertumbuhan panjang mutlak pada perlakuan $\mathrm{K}$ paling tinggi dibandingkan dengan perlakuan A dan B. Hanief dkk (2014), menyatakan bahwa frekuensi pemberian pakan berpengaruh terhadap pertumbuhan ikan. Pertumbuhan ikan umumnya akan lebih tinggi sejalan dengan tingginya frekuensi pemberian pakan terhadap ikan tersebut.

\section{DAFTAR PUSTAKA}
Boyd, C. E. 1979. Water Quality Management In Fish Pond Cultute Aquaculture Experiment Station. Auburn University. Alabama

Dardiani dan I.R Sary. 2010. Manajemen Penetasan Telur dan Pemeliharaan Larva Dalam Maman Sudrajat (Ed). Pusat Pengembangan dan Pemberdayaan Pendidik dan Tenaga Kependidikan Pertanian. Hal 1-8. 
Dias. 2012. Ikan Bawal Bintang. http://wikipedia.com. Diakses pada 26 Maret 2017.

Darmoni. A, dan M. Kadari. 2007. Pembesaran Ikan Bawal Bintang (Trachinotus blochii),

(Lacepede) di Keramba Jaring Apung dengan Pemberian Pakan Buatan (Pellet) yang Mempunyai Kadar Protein Berbeda. Balai Budidaya Laut Batam Direktorat Jenderal Perikanan Budidaya Departemen Kelautan dan Perikanan. Batam.

Effendie, M. I. 2002. Biologi Perikanan. Yayasan Pustaka Nusantara, Yogyakarta. 5 hal.

Effendie MI. 1997. Biologi Perikanan. Yogyakarta (ID): Yayasan Pustaka Nusatama. Muhammad, Alimuddin, Carman O, Zairin MJr. 2013. Respons pertumbuhan ikan nila berbeda varietas yang diberi hormon pertumbuhan rekombinan. Laporan kemajuan penelitian untuk disertasi, Program Studi Ilmu Akuakultur, BDP-FPIK-IPB, siap terbit.

Erlania, Rusamedi, A. B. Prasetio, J. Haryadi. 2010. Dampak Manajemen Pakan dari Kegiatan Budidaya Ikan Nila (Oreochromis niloticus) Dikeramba Jaring Apung Terhadap Kualitas Perairan Danau Maninjau. Prosiding Forum Inovasi Teknologi Akuakultur.

Fran, Syachradjad., S. Arifin, dan J. Akbar., 2011. Pengembangan Budi Daya IkanIkan Rawa di Kabupaten Barito Kuala, Kalimantan Selatan. Laporan Penelitian Kerjasama Fakultas Perikanan Unlam dengan Dinas Perikanan dan Kelautan Kalimantan Selatan.

Galano, T.G., Perez, J.C., Gaxiola, G., \& Sanchez, J.A. 2003. Effect of feeding frequency on food intake, gastric evacuation and growth in juvenile snook, Centropomus undecimalis (BLOCH). Rev. Invest., 24(2):145154.

Groat, Derek R. 2002. Effects of feeding strategies on growth of Florida pompano (Trachinotus carolinus) in closed recirculating systems. Louisiana State University and Agricultural and Mechanical College.

Handajani dan Widodo. 2010. Nutrisi Ikan. UMM Press. Malang.

Hanief, M.A.R. Subandiyono, P. 2014. Pengaruh frekuensi pemberian pakan terhadap pertumbuhan dan Kelulushidupan benih tawes (puntius javanicus). Journal of Aquaculture Management and Technology. Volume 3, Nomor 4, Tahun 2014, Halaman 67-74

Jayakumar, A.K. Abdul Nazar, G. Tamilmani, M. Sakthivel, C. Kalidas, P. Rameshkumar, G. Hanumata Rao and G. Gopakumar. 2014. Evaluation Of Growth and Production Performance of Hatchery Produced Silver Pompano Trachinotus blochii (Lacépède, 1801) Fingerlings Under Brackishwater Pond Farming in India. Indian J. Fish, 61 (3): 58-62.

Juniyanto, N. M., Akbar S., Zakimin. 2008. Manajemen Pembesaran Bawal Bintang (Trachinotus blochii, Lacepede) di Keramba Jaring Apung. Lokasi Budidaya Laut Batam Direktorat Jenderal Perikanan Budidaya Departemen Kelautan dan Perikanan. Batam.

Kayano, Y., S. Yao, S. Yamamoto, and H. Nakagawah. 1993. Effects of feeding frequency on the growth and body constitutents of young red-spotted grouper, (Epinephelus-akarra). Aquaculture 110: 271-278.

Minjoyo. H, Prihaningrum. A, dan Istikomah. 2008. Pembesaran Bawal Bintang (Trachinotus blochii, Lacepede) Dengan Padat Tebar Berbeda di Keramba Jaring Apung. Diakses dari www.digilib.its.ac.id pada 23 Maret 2017.

National Research Council (NCR). 1977. Nutrion Warmwater Fishes National Academic of Science. Washington DC. 
Nuhman. 2008. Pengaruh Prosentase Pemberian Pakan Terhadap Kelangsungan Hidup dan Laju Pertumbuhan Udang Vannemei (Litopenaeus vannamei). Berkala Ilmiah Perikanan, 3 (1) : 35-39.

Retnani, H. T. dan Abdulgani, N. 2013. Pengaruh Salinitas terhadap Kandungan Protein dan Pertumbuhan Ikan Bawal Bintang (Trachinotus blochii). Jurnal Sains dan Seni. 2 (16).

Sih Yang Sim, M. Rimner, K. William and J.D. Toledo, K. Sugama, I. Rumengan and M.J. Phillips. 2005. Pedoman Praktis Pemberaian dan Pengelolaan Pakan untuk Budidaya Kerapu. Publikasi No. 2005-02 dari Asia-Pacifi c Marine Finfi sh Aquaculture Network. Hal. 1-18

Suwirya, K., N.A. Giri dan M. Marzuqi. 2005. Beberapa Kebutuhan Ikan dalam Pengembangan Pakan untuk Menunjang Budidaya Laut. Prosiding Seminar Riptek Kelautan Nasional. Balai Besar Riset Perikanan Budidaya Laut, Gondol. Bali. Hal. 5

Taufiq, Firdaus, dan Imelda Arisa. 2016. Pertumbuhan Benih Ikan Bawal Air Tawar (Colossoma macropomum) Pada Pemberian Pakan Alami Yang Berbeda. Jurnal Ilmiah Mahasiswa Kelautan dan Perikanan Unsyiah, 1 (3) : 355-365.

Yenni Sri Mulyani, Yulisman, dan Mirna Fitriani. 2014. Pertumbuhan dan Efisiensi Pakan Ikan Nila (Oreochromis niloticus) Yang Dipuasakan Secara Periodik. Jurnal Akuakultur Rawa Indonesia, 2 (1) : $1-12$.

Zulkhasyni, Firman, dan Rejo Sari. 2016. Pemberian Pakan Buatan Dengan Dosis Yang Berbeda Untuk Pertumbuhan Dan Kelangsungan Benih Ikan Putih (Tor sp) Dalam Upaya Domestikasi. Jurnal Agroqua 14 (2) : 49-55. 